\title{
Morphological Analysis of Major Segments of Coronary Artery Occlusion. Importance in Myocardial Revascularization Surgery
}

\author{
Análisis Morfológico de los Principales Segmentos de Oclusión de las Arterias Coronarias. \\ Importancia en la Cirugía de Revascularización Miocárdiaca
}

\begin{abstract}
Brenda Martínez-González; María del Carmen Theriot-Girón**; Norberto López-Serna***; Rodolfo Morales-Avalos*; Alejandro Quiroga-Garza*; Cynthia G. Reyes-Hernández*; Arnulfo Villanueva-Olivo****; Jorge I. Leyva-Villegas*; Adolfo Soto-Domínguez ${ }^{* * * *}$; David de la Fuente-Villarreal*; Rodrigo E. Elizondo-Omaña* \& Santos Guzmán-López
\end{abstract}

MARTÍNEZ-GONZÁLEZ, B.; THERIOT-GIRÓN, M. C.; LÓPEZ-SERNA, N; MORALES-AVALOS, R.; QUIROGA-GARZA, A.; REYES-HERNÁNDEZ, C. G.; VILLANUEVA-OLIVO, A.; LEYVA-VILLEGAS, J. I.; SOTO-DOMÍNGUEZ, A.; DE LA FUENTE-VILLARREAL, D.; ELIZONDO-OMAÑA, R. E. \& GUZMÁN-LÓPEZ, S. Morphological analysis of major segments of coronary artery occlusion. Importance in myocardial revascularization surgery. Int. J. Morphol., 33(4):1205-1212, 2015.

SUMMARY: Revascularization surgery should ensure morphological similarity between the coronary artery and the graft. This is an important factor for its duration and permeability. The aim of this study was to analyze the morphological characteristics and morphometrics of the coronary artery segments with greater occlusion. This was an observational, cross-sectional descriptive study that consisted of two phases. A macroscopic phase in which 11 cadaveric hearts were extracted and coronary dominance and length of the anterior interventricular artery (AIA), the right coronary artery (RCA) and the circumflex artery (CXA) were determined. In the microscopic phase a total of 77 segments of these arteries were obtained and the luminal diameter, wall thickness, and amount of elastic fibers and the presence and size of the atheroma were determined. Right coronary dominance was the most frequent. Total vessel length was $15.65 \pm 1.17$ $\mathrm{cm}$ for the AIA, $12.67 \pm 2.02 \mathrm{~cm}$ for the RCA and $8.79 \pm 2.5 \mathrm{~cm}$ for the CXA. Diameters ranged from $2.3 \mathrm{~mm}$ in the proximal segments and between $1.1 \mathrm{~mm}$ to $1.8 \mathrm{~mm}$ in the distal segments. Wall thickness in the proximal segments was between $354 \mu \mathrm{m}$ and $396 \mu \mathrm{m}$ and in the distal segments it ranged from $120 \mu \mathrm{m}$ to $305 \mu \mathrm{m}$. The amount of elastic fibers showed that they were muscular arteries. Atheromas were present in 35\% in the CXA, and in 32.5\% in the AIA and the RCA. The largest ones were found in the proximal segments. This study examined the morphology and morphometry of the segments of the coronary arteries that are more frequently occluded. It provides information on the most significant parameters to be considered for election of the vascular graft in myocardial revascularization surgery.

KEY WORDS: Coronary artery; Morphology; Morphometry; Myocardial revascularization surgery.

\section{INTRODUCTION}

Cardiovascular diseases are the leading cause of death worldwide with coronary heart disease being the most frequent (Claes et al., 2008). Myocardial revascularization using a vascular graft is considered an effective and lasting therapy (González Santos et al., 2005). The morphological characteristics of the site of occlusion of the coronary artery are important criteria for the selection of the graft (Appleson \& Hill, 2012; He, 2006). The morphological similarity between the graft and the coronary artery is an important factor in its duration and permeability (Appleson \& Hill, Claes et al.; He). Therefore, it is of great importance to study the morphological characteristics of the coronary arteries at the sites that are most frequently occluded.
The arteries with a greater incidence of occlusion in the coronary circulation are: the anterior interventricular artery (AIA) in its proximal, middle and distal segments; the right coronary artery (RCA) and the circumflex (CXA) at its proximal and distal segments (Herzog et al., 2007; Rodriguez-Mendoza et al., 2010;. \& Rahimtoola Rosch, 1977; Wang et al., 2004).

There are numerous studies that analyze the morphology of the coronary arteries (Aroche Aportela et al., 2013; Ballesteros et al., 2011; Ballesteros \& Ramirez, 2008; Barry et al., 2003, 2007; Bastarrika et al., 2008; Ilayperuma et al., 2011; Unlü et al., 2003) with the luminal diameter

Departamento de Anatomía Humana, Facultad de Medicina, Universidad Autónoma de Nuevo León, Nuevo León, México.

** Departamento de Anatomía Humana, Facultad de Odontología, Universidad Autónoma de Nuevo León, Nuevo León México.

*** Departamento de Embriología, Facultad de Medicina, Universidad Autónoma de Nuevo León, Nuevo León, México.

***** Departamento de Histología, Facultad de Medicina, Universidad Autónoma de Nuevo León, Nuevo León, México. 
MARTÍNEZ-GONZÁLEZ, B.; THERIOT-GIRÓN, M. C.; LÓPEZ-SERNA, N; MORALES-AVALOS, R.; QUIROGA-GARZA, A.; REYES-HERNÁNDEZ, C. G.; VILLANUEVA-OLIVO, A.; LEYVA-VILLEGAS, J. I.; SOTO-DOMÍNGUEZ, A.; DE LA FUENTE-VILLARREAL, D.; ELIZONDO-OMAÑA, R. E. \& GUZMÁN-LÓPEZ, S. Morphological analysis of major segments of coronary artery occlusion. Importance in myocardial revascularization surgery. Int. J. Morphol., 33(4):1205-1212, 2015.

parameter being the most studied. However, there is little evidence regarding the length, wall thickness, and composition of the tunica media of these arteries (Unlü et al.). Furthermore, in most of these studies these parameters are typically measured in one segment (Ballesteros et al., 2011; Barry et al., 2003; Ilayperuma et al.; Unlü et al.) and some do not define the segment studied (Aroche Aportela $e t$ al.; Ballesteros \& Ramirez, 2008; Barry et al., 2007). The aim of this study was to analyze the morphological and morphometric characteristics of the coronary artery segments that most commonly present occlusion (the AIA, the RCA and The CXA).

\section{MATERIAL AND METHOD}

We preformed an observational, cross-sectional, descriptive study that studied the morphological and morphometric characteristics of 77 segments of the AIA, the RCA and the CXA from embalmed corpses, provided by the laboratories of Human Anatomy of the Faculties of Medicine and Dentistry of the Universidad Autónoma de Nuevo León.

This study was approved by the Research Ethics Committee of the School of Medicine and "Dr. José Eleuterio Gonzalez University Hospital of the Autonomous University of Nuevo Leon.

This study consisted of two phases: macroscopic and microscopic. In the macroscopic phase, coronary dominance and the length of each vessel were determined; in the microscopic phase, the luminal diameter, wall thickness, amount of elastic fibers in the tunica media, and the presence of atheroma and its size were determined.

The macroscopic phase consisted of extracting 11 hearts in a standardized manner. Two horizontal cuts, one between the middle portions of both clavicles and another below the xiphoid process following the costal margins were performed; plus a vertical cut, which connects the middle portions of the horizontal cuts. Flaps were retracted to the anterior axillary lines and costal cartilages were sectioned 2 $\mathrm{cm}$ from the lateral border of the sternum to remove the sternocostal plate. The lungs were retracted, the parietal pericardium was dissected, the root of the great vessels was sectioned, and the heart extracted.

The AIA, the RCA and the CXA were dissected and coronary dominance was determined in each heart. Right dominance was defined when the posterior interventricular artery (PIVA) originated from the RCA and left dominance when the PIVA came from the CXA. A balanced or codominant circulation was established when the PIVA originated from the RCA and the CXA provided posterolateral branches to the underside of the left ventricle (Ballesteros et al., 2007; Bastarrika et al.)

The length of the AIA was determined from its origin in the left coronary artery to the apex of the heart. The RCA was measured from its origin in the ascending aorta to before forming the PIVA or to its right border, according to the dominance found. CXA length was determined from its origin in the left coronary artery to the first posterolateral branch intended for the lower wall of the left ventricle or before issuing the PIVA in the case of a left coronary dominance. This was done by placing a flexible measuring tape over its entire length. Later, this was measured with a digital millimetric vernier with a precision of $0.01 \mathrm{~mm}$ (Mitutoyo Digimatic w/Absolute Encoders- Series 500) and the findings were reported in centimeters.

For the microscopic phase seven segments of each of the hearts were obtained. From the AIA, the proximal, middle and distal segment were obtained; while for the RCA and the CXA only the proximal and distal segments were used. These were preserved in a solution of $10 \%$ formalin, and processed by routine histological techniques and embedded in paraffin. Slices of $10 \mu \mathrm{m}$ were obtained and stained with hematoxylin and eosin, Masson's trichrome and Orcein.

Sections were examined in a bright field microscope at a magnification of 10x and 40x. Digital images were obtained and a morphometric analysis was made in which the lumen diameter, wall thickness, amount of elastic fibers in the tunica media, and atheroma size were determined.

The luminal diameter of each segment was obtained by calculating the mean of five straight linear measurements, which join two points on the luminal circumference passing through its center.

The thickness of the tunica media-intima and the thickness of the tunica media were determined obtaining the mean of five measurements for each segment. The thickness of the tunica media - intima was measured from the endothelium to the external elastic membrane and the tunica media from the internal elastic membrane to the external elastic membrane.

Orcein staining was used to quantify the number of elastic fibers in the tunica media, also counting the internal and external elastic membranes. When an atheroma was present, its size was determined by averaging three 
MARTÍNEZ-GONZÁLEZ, B.; THERIOT-GIRÓN, M. C.; LÓPEZ-SERNA, N; MORALES-AVALOS, R.; QUIROGA-GARZA, A.; REYES-HERNÁNDEZ, C. G.; VILLANUEVA-OLIVO, A.; LEYVA-VILLEGAS, J. I.; SOTO-DOMÍNGUEZ, A.; DE LA FUENTE-VILLARREAL, D.; ELIZONDO-OMAÑA, R. E. \& GUZMÁN-LÓPEZ, S. Morphological analysis of major segments of coronary artery occlusion. Importance in myocardial revascularization surgery. Int. J. Morphol., 33(4):1205-1212, 2015.

measurements from the endothelium to the internal elastic membrane. All these measures were obtained using the AxioVs40 V 4.8.1.0 computer program for Windows XP.

The results were analyzed with SPSS version 20.0 for reporting and interpretation. The mode and range were used for quantification of the elastic fibers, and the mean and standard deviation was determined the rest of the measurements.

\section{RESULTS}

In this study, the morphological and morphometric characteristics of 77 segments of the coronary artery (the AIA, the RCA and the CXA), which are more frequently occluded in patients with coronary disease, were analyzed.

Right coronary artery dominance was present in $72.73 \%$ of the hearts studied. In $18.18 \%$ there was left dominance. A balanced or co-dominant circulation was present in $9.09 \%$ of hearts. The mean length of the AIA was $15.66 \mathrm{~cm}( \pm 1.12)$, of the RCA $12.69 \mathrm{~cm}( \pm 1.94)$ and of the CXA $8.89 \mathrm{~cm}( \pm 2.11)$.

The luminal diameter, wall thickness and the amount of elastic fibers found in the tunica media are shown in Table I. The number of elastic fibers was low, most were discontinuous and with a loss of shape. Likewise, the internal elastic membrane of all segments was discontinuous (Fig. 1). The segments with the greatest number of elastic fibers were the proximal segments which presented a mode between 4 and 5, while the distal segments showed a mode of three elastic fibers.

The incidence and size of atheromas found in the coronary arteries are shown in Table II. In $51.95 \%$ of the studied segments (44 of 77), an atheroma was present in the wall. Of these, the AIA and RCA had a presence of $32.5 \%$ (13), respectively, and in the CXA it was $34 \%$ (14). The proximal segments had the greatest number of atherosclerotic plaques. The largest atheromas were observed in the proximal segments and the smaller ones in the distal segments.

Table I. Microscopic study. Luminal diameter, wall thickness and amount of elastic fibers of the segments studied $(\mathrm{n}=77)$.

\begin{tabular}{llcccrr}
\hline \multirow{2}{*}{ Artery } & \multirow{2}{*}{$\begin{array}{c}\text { Luminal } \\
\text { diameter }\end{array}$} & \multicolumn{2}{c}{ Wall thickness } & $\begin{array}{c}\text { Number of } \\
\text { elastic fibers }\end{array}$ \\
\cline { 3 - 7 } & & Mean \pm SD $(\mathbf{m m})$ & $\begin{array}{c}\text { Tunica media } \\
\text { Mean } \pm \text { SD }(\boldsymbol{\mu m})\end{array}$ & $\begin{array}{c}\text { Tunica media-intima } \\
\text { Mean } \pm \text { SD }(\boldsymbol{\mu m})\end{array}$ & Mode & Range \\
\hline \multirow{2}{*}{ AIA } & Proximal & $2.37 \pm 0.47$ & $164.52 \pm 58.68$ & $354.39 \pm 98.72$ & 5 & $2-7$ \\
& Middle & $1.50 \pm 0.31$ & $103.07 \pm 46.66$ & $218.79 \pm 113.36$ & 3 & $3-5$ \\
& Distal & $1.12 \pm 0.31$ & $63.42 \pm 19.95$ & $117.59 \pm 34.41$ & 3 & $2-4$ \\
\multirow{2}{*}{ RCA } & Proximal & $2.31 \pm 0.76$ & $171.53 \pm 66.9$ & $396.31 \pm 105.47$ & 4 & $3-6$ \\
& Distal & $1.81 \pm 0.43$ & $129.76 \pm 57.25$ & $305.52 \pm 111.08$ & 3 & $2-5$ \\
\multirow{2}{*}{ CXA } & Proximal & $2.33 \pm 0.57$ & $148.70 \pm 44.58$ & $361.37 \pm 132.42$ & 4 & $2-5$ \\
& Distal & $1.51 \pm 0.43$ & $109.62 \pm 47.94$ & $227.59 \pm 118.11$ & 3 & $3-5$ \\
\hline
\end{tabular}

Masson trichrome staining and Orcein were used to obtain these parameters. The luminal diameters are constant in the proximal and distal segments. The size of the intima is variable between segments (Fig. 2). The elastic fibers in the tunica media are scarce.

Table II. Microscopic study. Incidence and size of atheromas in the segments studied $(n=77)$.

\begin{tabular}{llccc}
\hline Artery & Segment & $\begin{array}{c}\text { Incidence of } \\
\text { atheromas }(\%)\end{array}$ & $\begin{array}{c}\text { Percentage of atheromas } \\
\text { with regard to Incidence }\end{array}$ & $\begin{array}{c}\text { Size of atheroma } \\
\text { Mean } \pm \text { SD }(\boldsymbol{\mu m})\end{array}$ \\
\hline \multirow{3}{*}{ AIA } & Proximal & $8(72.72)$ & 20 & $1021.97 \pm 163.91$ \\
& Middle & $3(27.27)$ & 7.5 & $498.66 \pm 280.92$ \\
& Distal & $2(18.18)$ & 5 & $519.67 \pm 198.09$ \\
\multirow{2}{*}{ RCA } & Proximal & $8(72.72)$ & 20 & $769.10 \pm 205.27$ \\
& Distal & $5(45.45)$ & 12.5 & $520.83 \pm 326.78$ \\
CXA & Proximal & $8(72.72)$ & 20 & $804.72 \pm 367.95$ \\
& Distal & $6(54.54)$ & 15 & $589.30 \pm 253.91$ \\
\hline
\end{tabular}

Staining was performed with hematoxylin and eosin and Masson's trichrome to obtain these results. Atherosclerotic plaques were present in $51.95 \%$ of the segments, most were located in the CXA. Atheromas appeared in $60 \%$ of the proximal segments and these were the largest. 
MARTÍNEZ-GONZÁLEZ, B.; THERIOT-GIRÓN, M. C.; LÓPEZ-SERNA, N; MORALES-AVALOS, R.; QUIROGA-GARZA, A.; REYES-HERNÁNDEZ, C. G.; VILLANUEVA-OLIVO, A.; LEYVA-VILLEGAS, J. I.; SOTO-DOMÍNGUEZ, A.; DE LA FUENTE-VILLARREAL, D.; ELIZONDO-OMAÑA, R. E. \& GUZMÁN-LÓPEZ, S. Morphological analysis of major segments of coronary artery occlusion. Importance in myocardial revascularization surgery. Int. J. Morphol., 33(4):1205-1212, 2015.

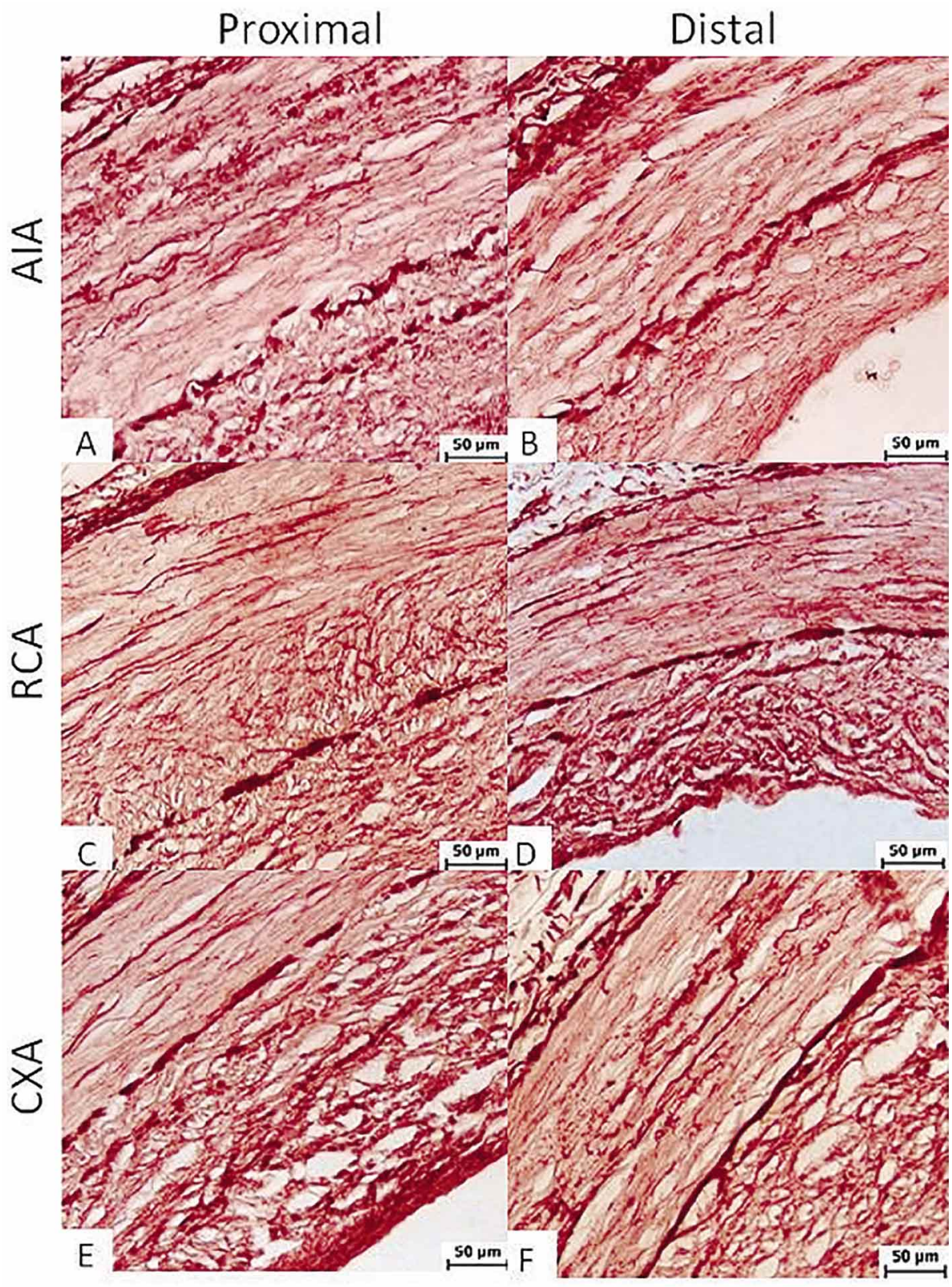

Fig. 1. Elastic fibers in the media of the proximal and distal segments of the AIA, RCA and the CXA. Cross-sections of the coronary arteries stained with Orcein. Objective 40x. Scarce elastic fibers with a loss of form in the tunica media and a fragmented internal

\section{DISCUSSION} elastic membrane.

In recent decades there have been numerous studies analyzing the morphology of the coronary arteries (Aroche Aportela et al.; Ballesteros et al., 2011; Ballesteros \& Ramirez; Barry et al., 2003, 2007; Bastarrika et al.; Ilayperuma et al.; Rösch \& Rahimtoola; Unlü et al.; Wang et al.). However, few describe the length, wall composition (Unlü et al.), and morphological characteristics of atheromas (Rösch \& Rahimtoola). In this paper, we present a morphological and morphometric analysis of the segments of the coronary arteries most frequently occluded. This is very important because we focus on the most significant morphological and morphometric parameters that must be considered for the proper selection of the graft in coronary artery bypass grafting (Ballesteros et al., 2007; He; Kalpana, 2003; Mills \& Pigott, 1996). 
MARTÍNEZ-GONZÁLEZ, B.; THERIOT-GIRÓN, M. C.; LÓPEZ-SERNA, N; MORALES-AVALOS, R.; QUIROGA-GARZA, A.; REYES-HERNÁNDEZ, C. G.; VILLANUEVA-OLIVO, A.; LEYVA-VILLEGAS, J. I.; SOTO-DOMÍNGUEZ, A.; DE LA FUENTE-VILLARREAL, D.; ELIZONDO-OMAÑA, R. E. \& GUZMÁN-LÓPEZ, S. Morphological analysis of major segments of coronary artery occlusion. Importance in myocardial revascularization surgery. Int. J. Morphol., 33(4):1205-1212, 2015.

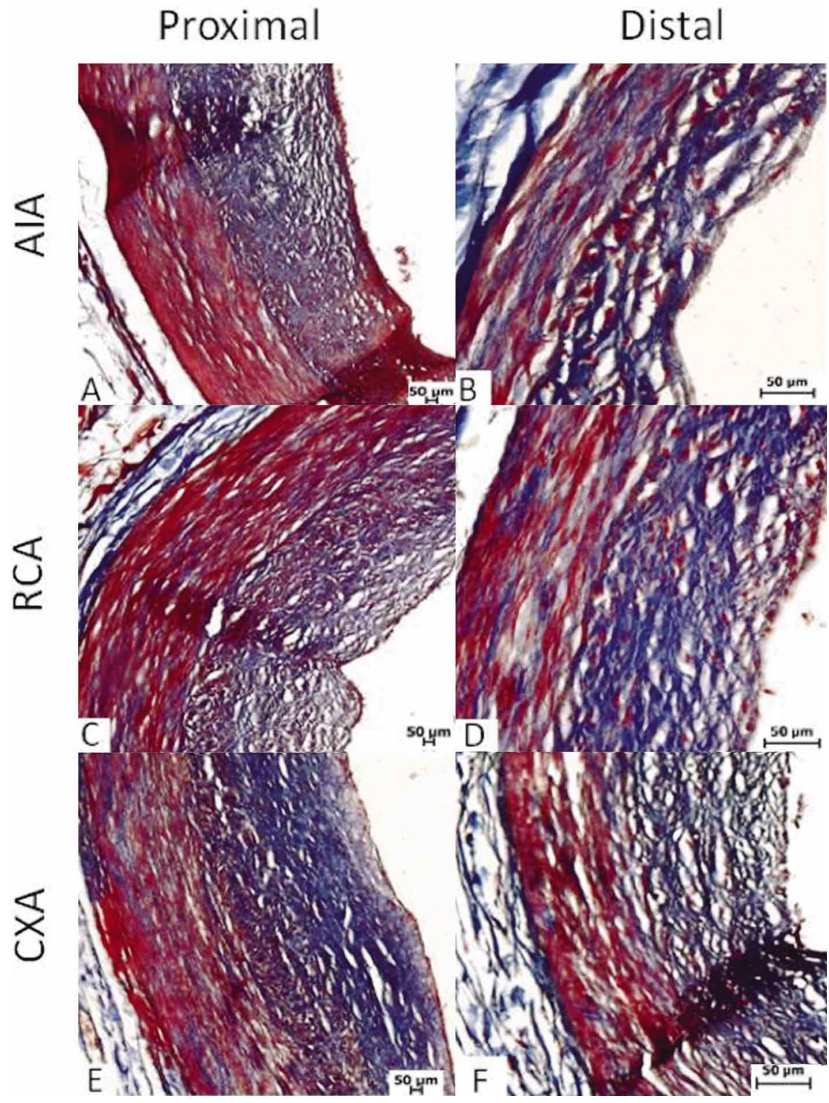

Fig. 2. Intima-media wall thickness of the proximal and distal segments of the AIA, RCA and CXA. Cross-sectional sections stained with Masson's trichrome. Objectives 10x and 40x. Unlike the tunica media, the size of the intima is greater and varies between segments.

There are studies that describe the dominance of the coronary arteries (Ballesteros et al., 2007, 2011; Bastarrika et al.). The frequency of right heart dominance mentioned was between $76 \%$ and $85 \%$, balanced flow was between $17 \%$ and $7.5 \%$, and left dominance was between $7.5 \%$ and $6.8 \%$. Our results agree with those reported in the literature for other populations.

There is little evidence on the length and wall thickness of the coronary arteries, in contrast with the luminal diameter, which is the most studied parameter. Unlü et al., determined the length of the AIA, the RCA and the CXA in Turkish population and found results inferior to ours (Table III). We analyzed the luminal diameter and wall thickness in only one segment of each artery (Ballesteros et al., 2011; Barry et al., 2003; Ilayperuma et al.; Unlü et al.) or in one unspecified (Aroche Aportela et al.; Ballesteros \& Ramirez; Barry et al., 2007) (Table III). The luminal diameter obtained by Barry et al. $(2003,2007)$ in French population and by
Unlü et al. In Turkish population are similar to those in our study (Table III). Also, Unlü et al., determined the thickness of the wall in only midsegments and obtained results lower than ours. In the present study, we analyzed various segments. This provides information for selection of a specific segment for a particular graft.

In Table I we see that both segments of the RCA had a luminal diameter and a wall thickness that was greater compared to the rest. This is probably because most hearts had a right coronary dominance, therefore this artery was larger. Furthermore, the size of the intima was greater and varied between segments (Table I, Fig. 2). Subbotin (2007) mentioned that the coronary arteries are vessels where hyperplasia of the intima is a normal process that perhaps precedes the atherosclerotic process.

The differences in length, wall thickness, and lumen diameter between other studies and ours (Table III) could be due to the different characteristics between populations (Moreno-Estrada et al., 2014), the amount of study sample, or the site and way the measurement was made, since in most studies it is not specified.

There is no evidence on the amount and distribution of elastic fibers in the tunica media of coronary arteries. According to our results, the coronary arteries are mainly muscular (Table I). Knowing the amount of elastic fibers is important to know if the graft will withstand the pressures of the coronary circulation. It has been stated that the more elastic the graft, the greater the permeability, although this has not been proven ( $\mathrm{He})$. It has also shown that there is a correlation between the absence of elastic fibers and the presence of discontinuities in the internal elastic membrane. This enhances the development of intimal hyperplasia and graft occlusion (van Son et al., 2006). Due to this, venous grafts such as those of the saphenous vein (which have little elastic fibers in the tunica media) do not have a durable permeability in contrast to arterial grafts.

In general, it is reported that atheromas occur most frequently in the AIA, the RCA and the CXA (Herzog et al., 2007; Mendoza-Rodríguez et al., 2010; Wang et al.), but most do not specify in which segments they are located. Rösch \& Rahimtoola, divided the entire coronary tree into 15 segments, and reported that they frequently occur in proximal segments. Our results agree with those obtained in this study.

We found no evidence on the size of atheromas in other studies. It is important to study this parameter because according to He, the severity of coronary artery disease is a factor in determining the graft to be used in surgery. In our 
MARTÍNEZ-GONZÁLEZ, B.; THERIOT-GIRÓN, M. C.; LÓPEZ-SERNA, N; MORALES-AVALOS, R.; QUIROGA-GARZA, A.; REYES-HERNÁNDEZ, C. G.; VILLANUEVA-OLIVO, A.; LEYVA-VILLEGAS, J. I.; SOTO-DOMÍNGUEZ, A.; DE LA FUENTE-VILLARREAL, D.; ELIZONDO-OMAÑA, R. E. \& GUZMÁN-LÓPEZ, S. Morphological analysis of major segments of coronary artery occlusion. Importance in myocardial revascularization surgery. Int. J. Morphol., 33(4):1205-1212, 2015.

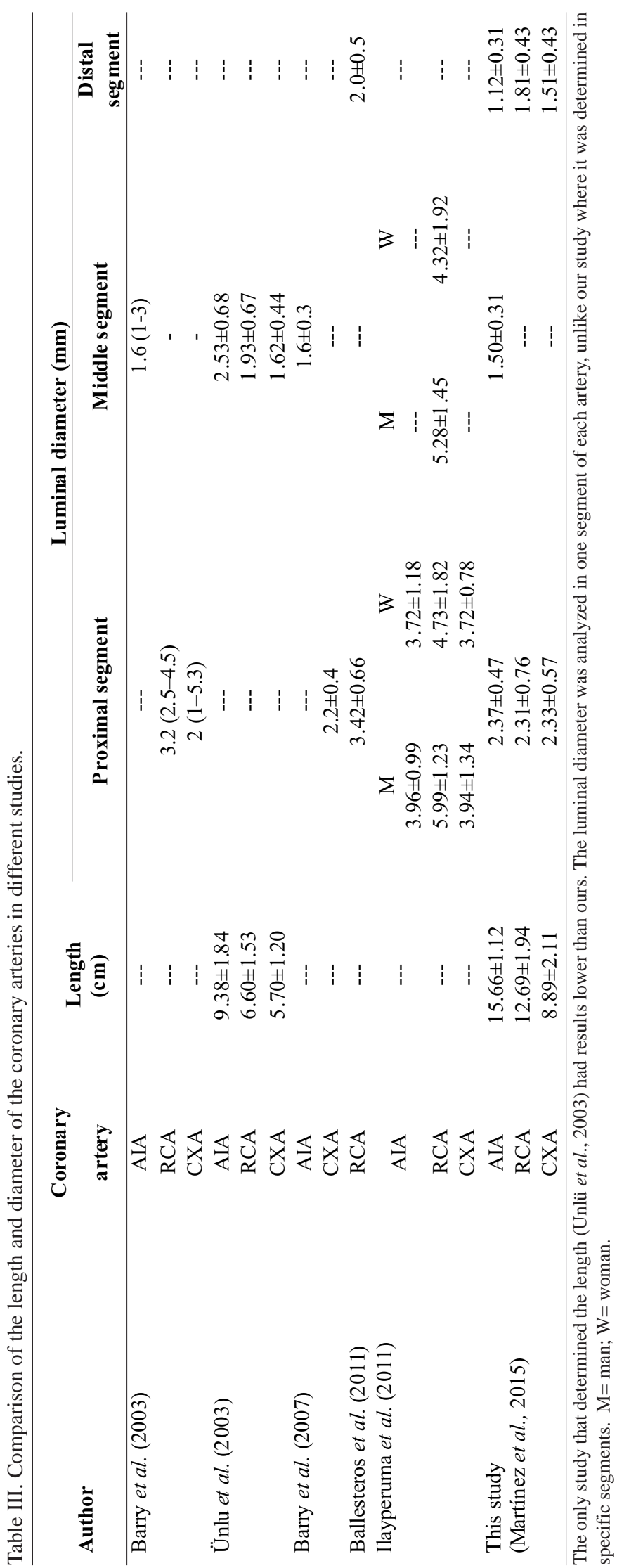

study, larger atherosclerotic plaques were found in the proximal segments; most likely because these have a larger luminal diameter. We also found that larger atheromas had a thicker intima. Moreno et al. (2002) and López-Mínguez et al. (2006) mention that atherosclerotic plaque frequently forms in the most proximal segments and that changes such as rupture of the internal elastic membrane and atrophy of the tunica media with a decrease in thickness and the amount of elastic fibers, occur in the wall. These changes coincide with what we found during microscopic analysis.

It is noteworthy to mention that this study has certain limitations. Similar studies with larger samples that take into account age, gender, and weight of the cadavers and that use imaging studies that more precisely establish the evaluated parameters, are required.

In conclusion, the present study examined the morphology and morphometry of the segments of the coronary arteries that are more frequently occluded. It provides information on the most significant parameters of the segments of the AIA, RCA and CXA arteries, which must be considered for selection of the vascular graft in myocardial revascularization.

\section{ACKNOWLEDGEMENTS}

We thank the staff of the Human Anatomy, Embryology and Histology Departments of the U.A.N.L. School of Medicine and the Human Anatomy Department of the U.A.N.L. School of Dentistry for their support and confidence. We also thank the chemists, Griselda Laredo López and Evangelina Alvarez González, for their support and help in performing the staining used in this study.

MARTÍNEZ-GONZÁLEZ, B.; THERIOT-GIRÓN, M. C.; LÓPEZ-SERNA, N; MORALES-AVALOS, R.; QUIROGA-GARZA, A.; REYES-HERNÁNDEZ, C. G.; VILLANUEVA-OLIVO, A.; LEYVA-VILLEGAS, J. I.; SOTO-DOMÍNGUEZ, A.; DE LA FUENTEVILLARREAL, D.; ELIZONDO-OMAÑA, R. E. \& GUZMÁN-LÓPEZ, S. Análisis morfológico de los principales segmentos de oclusión de las arterias coronarias. Importancia en la cirugía de revascularización miocárdiaca. Int. J. Morphol., 33(4):1205-1212, 2015.

RESUMEN: En la cirugía de revascularización 
MARTÍNEZ-GONZÁLEZ, B.; THERIOT-GIRÓN, M. C.; LÓPEZ-SERNA, N; MORALES-AVALOS, R.; QUIROGA-GARZA, A.; REYES-HERNÁNDEZ, C. G.; VILLANUEVA-OLIVO, A.; LEYVA-VILLEGAS, J. I.; SOTO-DOMÍNGUEZ, A.; DE LA FUENTE-VILLARREAL, D.; ELIZONDO-OMAÑA, R. E. \& GUZMÁN-LÓPEZ, S. Morphological analysis of major segments of coronary artery occlusion. Importance in myocardial revascularization surgery. Int. J. Morphol., 33(4):1205-1212, 2015.

miocárdica se debe asegurar la similitud morfológica entre la arteria coronaria y el injerto. Esto es un factor importante en su duración y permeabilidad. El objetivo fue analizar las características morfológicas y morfométricas de los segmentos de mayor oclusión de las arterias coronarias. Estudio observacional, transversal y descriptivo que constó de dos fases. Una macroscópica en la que se extrajeron 11 corazones de cadáveres y se determinó la dominancia coronaria y longitud de la arteria interventricular anterior (AIA), la arteria coronaria derecha (ACD) y la arteria circunfleja (ACX). En la fase microscópica se obtuvo un total de 77 segmentos de estas arterias y se determinó el diámetro luminal, grosor de pared, cantidad de fibras elásticas y presencia y tamaño de ateroma. La dominancia coronaria derecha fue la más frecuente. La longitud total de los vasos fue de $15,65 \pm 1,17 \mathrm{~cm}$ para la AIA, de $12,67 \pm 2,02 \mathrm{~cm}$ para la ACD y $8,79 \pm 2,5 \mathrm{~cm}$ para la ACX. Los diámetros oscilaron entre los $2,3 \mathrm{~mm}$ en los segmentos proximales y entre $1,1 \mathrm{~mm}$ a $1,8 \mathrm{~mm}$ en los segmentos distales. Los grosores de pared en los segmentos proximales se presentaron entre $354 \mu \mathrm{m}$ y $396 \mu \mathrm{m}$ y en los segmentos distales oscilaron entre $120 \mu \mathrm{m}$ a 305 $\mu \mathrm{m}$. La cantidad de fibras elásticas demostró que son arterias musculares. El 35\% de los ateromas se presentó en la ACX y el 32,5\% en la AIA al igual que en la ACD. Los de mayor tamaño se encontraron en los segmentos proximales. Este estudio analizó la morfología y la morfometría de los segmentos de las arterias coronarias que se ocluyen con mayor frecuencia. Los resultados encontrados aporta información sobre los parámetros más significativos que se deben considerar para la elección del injerto vascular en la cirugía de revascularización miocárdica.

PALABRAS CLAVE: Arterias coronarias; Morfología; Morfometría; Cirugía de revascularización miocárdica.

\section{REFERENCES}

Appleson, T. \& Hill, R. V. Histological comparison of the candidate arteries for bypass grafting of the posterior interventricular branch. Anat. Sci. Int., 87(3):150-4, 2012.

Aroche Aportela, R.; Obregon Santos, A. G.; Rodriguez Fontaine, Y.; Aldama Perez, L. I. \& Rodríguez Navarro, A. Y. Caracterización cualitativa y cuantitativa de las arterias coronarias de la población cubana. Investig. Medicoquir., 5(1):84-99, 2013.

Ballesteros, A. L. E.; Corzo, G. E. G. \& Saldarriaga, T. B. Determinación de la dominancia coronaria en población mestiza colombiana. Un estudio anatómico directo. Int. J. Morphol., 25(3):483-91, 2007.

Ballesteros, L. E. \& Ramirez, L. M. Morphological expression of the left coronary artery: a direct anatomical study. Folia Morphol. (Warsz.), 67(2):135-42, 2008.

Ballesteros, L. E.; Ramirez, L. M. \& Quintero, I. D. Right coronary artery anatomy: anatomical and morphometric analysis. Rev. Bras. Cir. Cardiovasc., 26(2):230-7, 2011.
Barry, M. M.; Foulon, P.; Touati, G.; Ledoux, B.; Sevestre, H.; Carmi, D. \& Laude, M. Comparative histological and biometric study of the coronary, radial and left internal thoracic arteries. Surg. Radiol. Anat., 25(3-4):284-9, 2003.

Barry, M.; Touati, G.; Chardon, K.; Laude, M.; Libert, J. P. \& Sevestre, H. Histologic study of coronary, radial, ulnar, epigastric and internal thoracic arteries: application to coronary artery bypass grafts. Surg. Radiol. Anat., 29(4):297$302,2007$.

Bastarrika, A. G.; Alonso, B. A.; Azcárate, A. P. M.; Castaño, R. S.; Pueyo, V. J. C. \& Alegría, E. E. Anatomía normal, variantes anatómicas y anomalías del origen y trayecto de las arterias coronaries por tomografía computarizada multicorte. Radiol., 50(3):197-206, 2008.

Claes, E.; García Herrera, C. M.; Guinea Tortuero, G. V.; Bernal Marcos, J. M.; Revuelta Soba, J. M. \& Elices Calafat, M. Análisis mecánico de un bypas coronario termino-terminal. An. Mec. Fract, 25(2):11-6, 2008.

González Santos, J. M.; López Rodriguez, J. \& Dalmau Sorlí, M. J. Los injertos arteriales en cirugía coronaria: ¿una terapia universal? Rev. Esp. Cardiol., 58(10):1207-23, 2005.

He, G. W. Considerations in the choice of arterial grafts. Arterial Grafting for Coronary Artery Bypass Surgery. Heidelberg, Springer Berlin Heidelberg, 2006. pp.81-6.

Herzog, C.; Zwerner, P. L.; Doll, J. R.; Nielsen, C. D.; Nguyen, S. A.; Vogl, T. J.; Costello, P. \& Schoepf, U. J. Significant coronary artery stenosis: comparison on per-patient and pervessel or per-segment basis at 64-section CT angiography. Radiology, 244(1):112-20, 2007.

Ilayperuma, I.; Nanayakkara, B. G. \& Palahepitiya, K. N. Sexual differences in the diameter of coronary arteries in an adult Sri Lankan population. Int. J. Morphol., 29(4):1444-8, 2011.

Kalpana, R. A study on principal branches of coronary arteries in humans. J. Anat. Soc. India, 52(2):137-40, 2003.

López-Mínguez, J. R.; Climent, V.; Yen-Ho, S.; GonzálezFernández, R.; Nogales-Asensio, J. M. \& Sánchez-Quintana, D. Características estructurales de los senos de Valsalva y porción proximal de las arterias coronarias. Su relevancia durante la disección retrógrada aortocoronaria. Rev. Esp. Cardiol., 59(7):696-702, 2006.

Mendoza-Rodríguez, V.; Llerena, L. R.; Rodríguez-de la Vega, A. \& Rodríguez-Díaz, Y. Volumen de placas coronarias calcificadas por tomografía computarizada y presencia de estenosis significativa por angiografía coronaria. Arch. Cardiol. Mex., 80(3):181-6, 2010.

Mills, N. \& Pigott, J. Arterial conduits for coronary artery bypass. Oper. Tech. Card. Thoracic Surg., 1(2):172-84, 1996. 
MARTÍNEZ-GONZÁLEZ, B.; THERIOT-GIRÓN, M. C.; LÓPEZ-SERNA, N; MORALES-AVALOS, R.; QUIROGA-GARZA, A.; REYES-HERNÁNDEZ, C. G.; VILLANUEVA-OLIVO, A.; LEYVA-VILLEGAS, J. I.; SOTO-DOMÍNGUEZ, A.; DE LA FUENTE-VILLARREAL, D.; ELIZONDO-OMAÑA, R. E. \& GUZMÁN-LÓPEZ, S. Morphological analysis of major segments of coronary artery occlusion. Importance in myocardial revascularization surgery. Int. J. Morphol., 33(4):1205-1212, 2015.

Moreno, P. R.; Purushothaman, K. R.; Fuster, V. \& O’Connor, W. N. Intimomedial interface damage and adventitial inflammation is increased beneath disrupted atherosclerosis in the aorta: implications for plaque vulnerability. Circulation, 105(21):2504-11, 2002.

Moreno-Estrada, A.; Gignoux, C. R.; Fernández-López, J. C.; Zakharia, F.; Sikora, M.; Contreras, A. V.; Acuña-Alonzo, V.; Sandoval, K.; Eng, C.; Romero-Hidalgo, S.; Ortiz-Tello, P.; Robles, V.; Kenny, E. E.; Nuño-Arana, I.; Barquera-Lozano, R.; Macín-Pérez, G.; Granados-Arriola, J.; Huntsman, S.; Galanter, J. M.; Via, M.; Ford, J. G.; Chapela, R.; RodriguezCintron, W.; Rodríguez-Santana, J. R.; Romieu, I.; SienraMonge, J. J.; del Rio Navarro, B.; London, S. J.; Ruiz-Linares, A.; Garcia-Herrera, R.; Estrada, K.; Hidalgo-Miranda, A.; Jimenez-Sanchez, G.; Carnevale, A.; Soberón, X.; CanizalesQuinteros, S.; Rangel-Villalobos, H.; Silva-Zolezzi, I.; Burchard, E. G. \& Bustamante, C. D. Human genetics. The genetics of Mexico recapitulates Native American substructure and affects biomedical traits. Science, 344(6189):1280-5, 2014.

Rösch, J. \& Rahimtoola, S. H. Progression of angiographically determined coronary stenosis. Cardiovasc. Clin., 8(2):55-70, 1977.

Subbotin, V. M. Analysis of arterial intimal hyperplasia: review and hypothesis. Theor. Biol. Med. Model., 4:41, 2007.

Unlü, Y.; Keles, P.; Keles, S.; Yesilyurt, H.; Kocak, H. \& Diyarbakirli, S. An evaluation of histomorphometric properties of coronary arteries, saphenous vein, and various arterial conduits for coronary artery bypass grafting. Surg. Today, 33(10):725-30, 2003.

van Son, J. A. M.; Smedts, F. M. M.; Yang, C. Q. \& He, G. W. Histology and Comparison of Arterial Grafts Used for Coronary Surgery. Heidelberg, Springer, 2006. pp.3-16.

Wang, J. C.; Normand, S. L.; Mauri, L. \& Kuntz, R. E. Coronary artery spatial distribution of acute myocardial infarction occlusions. Circulation, 110(3):278-84, 2004.

\section{Correspondence to:}

Dr. C. Rodrigo E. Elizondo-Omaña

Grupo de Investigación en Anatomía (GIA)

Departamento de Anatomía Humana

Facultad de Medicina y Hospital Universitario "Dr. José Eleuterio González"

Universidad Autónoma de Nuevo León (UANL)

Ave. Madero s/n Col. Mitras Centro

Monterrey, Nuevo León, C.P.64460

MEXICO

Email: rod_omana@yahoo.com

Received: 09-01-2015

Accepted: 14-08-2015 